\title{
Questions and answers in Evidence-based Dentistry volume 11
}

\section{Derek Richards}

\section{Editor, Evidence-based Dentistry}

As in previous years, we highlight here the guidelines, questions and answers addressed by summaries in Evidence-based Dentistry. ${ }^{1-8}$

Evidence levels ${ }^{9}$ are only given for those papers that achieved level $3 \mathrm{~A}$ and above.

Evidence-Based Dentistry (2010) 11, 119-122. doi:10.1038/sj.ebd.6400762

\section{Clinical Recommendations}

\begin{tabular}{|l|l|l|l|}
\hline Topic Area & & & Page \\
\hline Oral Cancer & Evidence-based clinical recommendations regarding screening for oral squamous cell carcinomas & 101 \\
\hline
\end{tabular}

\section{Dental Evidence-based topics (DEBTs)}

\begin{tabular}{|l|l|l|l}
\hline Topic area & Question & Answer & Page \\
\hline $\begin{array}{l}\text { Restorative } \\
\text { dentistry }\end{array}$ & $\begin{array}{l}\text { In adult patients requiring a two surface or } \\
\text { larger restoration on a posterior tooth, is a } \\
\text { crown or onlay a better option than a composite } \\
\text { or amalgam restoration for tooth survival? }\end{array}$ & $\begin{array}{l}\text { There is no high quality evidence that supports or rejects } \\
\text { the practice of placing a crown or onlay on a vital posterior } \\
\text { tooth rather than a composite or amalgam restoration to } \\
\text { ensure longer tooth survival. }\end{array}$ & $\begin{array}{l}116 \\
\end{array}$
\end{tabular}

\begin{tabular}{|c|c|c|c|c|}
\hline Topic & Question & Answer & $\begin{array}{l}\text { Evidence } \\
\text { level }\end{array}$ & Page \\
\hline \multirow[t]{7}{*}{ Caries } & $\begin{array}{l}\text { What is the relative effectiveness } \\
\text { of fluoride toothpastes of different } \\
\text { concentrations in preventing dental } \\
\text { caries in children and adolescents? }\end{array}$ & $\begin{array}{l}\text { This review confirms the benefits of using fluoride toothpaste } \\
\text { in preventing caries in children and adolescents compared with } \\
\text { placebo. However this is only statistically significant at fluoride } \\
\text { concentrations of } 1000 \text { ppm and use for children aged under } 6 \\
\text { years should be balanced with the risk of fluorosis. The relative caries } \\
\text { preventive effects of fluoride toothpastes of different concentrations } \\
\text { increase with higher fluoride concentration. }\end{array}$ & $1 \mathrm{~A}$ & $6-7$ \\
\hline & $\begin{array}{l}\text { In children using topical fluorides } \\
\text { what is the risk of developing } \\
\text { fluorosis? }\end{array}$ & $\begin{array}{l}\text { There should be a balanced consideration of the benefits of topical } \\
\text { fluorides in caries prevention and the risk of the development of } \\
\text { fluorosis. There is weak unreliable evidence that starting the use of } \\
\text { fluoride toothpaste in children aged }<12 \text { months may be associated } \\
\text { with an increased risk of fluorosis. The evidence if use begins } \\
\text { between the age of } 12 \text { and } 24 \text { months is equivocal. If the risk of } \\
\text { fluorosis is of concern, the fluoride level of toothpaste for young } \\
\text { children (under } 6 \text { years of age) is recommended to be lower than } \\
1000 \text { parts per million (ppm). }\end{array}$ & $1 \mathrm{~A}$ & $8-9$ \\
\hline & $\begin{array}{l}\text { Is sealant retention as good } \\
\text { following tooth surface cleaning } \\
\text { with a toothbrush compared with } \\
\text { handpiece prophylaxis? }\end{array}$ & $\begin{array}{l}\text { The results indicate that retention of sealants after a supervised } \\
\text { toothbrush cleaning by the patient was at least as high as those } \\
\text { associated with a traditional handpiece prophylaxis. These findings may } \\
\text { translate into lower costs for materials, equipment and personnel. }\end{array}$ & $1 \mathrm{a}$ & $79-80$ \\
\hline & $\begin{array}{l}\text { In children and adolescents is } \\
\text { chlorhexidine varnish effective in } \\
\text { preventing caries? }\end{array}$ & $\begin{array}{l}\text { Chlorhexidine varnish does not appear to be effective for caries } \\
\text { prevention in children. }\end{array}$ & $1 b$ & 108 \\
\hline & $\begin{array}{l}\text { Is daily high dose xylitol chewing } \\
\text { gum more effective than non-xylitol } \\
\text { chewing gum at reducing plaque } \\
\text { acidogenicity and salivary mutans } \\
\text { streptoccoci? }\end{array}$ & $\begin{array}{l}\text { This randomised clinical trial suggests that the use of high-dose } \\
\text { xylitol chewing gum has beneficial effects on plaque } \mathrm{pH} \text { and mutans } \\
\text { streptoccoci in children at high risk of caries. }\end{array}$ & $1 b$ & 109 \\
\hline & $\begin{array}{l}\text { Is enamel matrix derivative as } \\
\text { effective as calcium hydroxide } \\
\text { for direct pulp capping of } \\
\text { primary molars? }\end{array}$ & $\begin{array}{l}\text { Direct pulp capping has been shown to be a successful technique } \\
\text { where there is not carious exposure. Given the high treatment } \\
\text { success rates of other techniques which are less invasive (indirect } \\
\text { pulp cap, stepwise caries removal, partial caries removal or the Hall } \\
\text { Technique), the clinician may wish to consider these options for } \\
\text { asymptomatic primary molars with deep caries. }\end{array}$ & $1 b$ & $45-6$ \\
\hline & $\begin{array}{l}\text { Which filling material should be used } \\
\text { for the treatment of caries in the } \\
\text { primary dentition? }\end{array}$ & $\begin{array}{l}\text { There was insufficient evidence from trials to make any } \\
\text { recommendations about which filling material to use. }\end{array}$ & $2 b$ & $4-5$ \\
\hline
\end{tabular}




\begin{tabular}{|c|c|c|c|c|}
\hline & $\begin{array}{l}\text { Does casein phosphopeptide- } \\
\text { amorphous calcium phosphate } \\
\text { prevent caries? }\end{array}$ & $\begin{array}{l}\text { There is preliminary evidence that casein phosphopeptide- } \\
\text { amorphous calcium phosphate can prevent caries, but until its } \\
\text { effectiveness has been quantified, practitioners should not rely on it } \\
\text { as a primary preventive treatment. }\end{array}$ & $2 b$ & $11-12$ \\
\hline & $\begin{array}{l}\text { Does dental prophylaxis provided } \\
\text { at recall appointments reduce caries } \\
\text { increments, or improve gingival health? }\end{array}$ & $\begin{array}{l}\text { Dental prophylaxis at intervals of four months or more is not justified } \\
\text { for the prevention of gingivitis in the general population. }\end{array}$ & $2 b$ & $16-17$ \\
\hline & $\begin{array}{l}\text { Are glass ionomer cements as } \\
\text { effective as resin-based fissure } \\
\text { sealants when used on permanent } \\
\text { teeth? }\end{array}$ & $\begin{array}{l}\text { Glass ionomer cements and resin-based sealants exhibited significant } \\
\text { caries preventive effects. This review found no evidence that either } \\
\text { material was superior to the other in the prevention of caries. } \\
\text { Therefore both materials appear to be equally suitable as fissure } \\
\text { sealant materials. }\end{array}$ & N/A & 10 \\
\hline \multirow[t]{3}{*}{$\begin{array}{l}\text { Oral health } \\
\text { promotion }\end{array}$} & $\begin{array}{l}\text { Does motivational interviewing } \\
\text { immediately before an oral health } \\
\text { education session enhance the } \\
\text { education effect? }\end{array}$ & $\begin{array}{l}\text { Results suggest that motivational interviewing is effective at } \\
\text { enhancing short term oral health behaviour change for people with } \\
\text { severe mental illness and may be useful for the general population. }\end{array}$ & $1 b$ & $14-15$ \\
\hline & $\begin{array}{l}\text { In routine care, does an evidence- } \\
\text { based intervention, framed with } \\
\text { psychological theory, improve } \\
\text { patients' oral hygiene behaviour? }\end{array}$ & $\begin{array}{l}\text { A simple, theory-based intervention delivered within the constraints } \\
\text { of a primary care environment was more effective than routine care in } \\
\text { influencing patients' oral hygiene cognitions, behaviour and health. As } \\
\text { clinical outcomes were significantly better only in the cluster RCT, the } \\
\text { impact of trial design on results needs to be explored further. }\end{array}$ & $1 b$ & 41 \\
\hline & $\begin{array}{l}\text { What health behaviour models are } \\
\text { used in oral health promotion and are } \\
\text { they effective? }\end{array}$ & $\begin{array}{l}\text { There is a need to develop an effective model for chairside oral } \\
\text { health promotion that incorporates this evidence and allows } \\
\text { oral health professionals to focus more on the underlying social } \\
\text { determinants of oral disease during the clinical encounter. There is } \\
\text { potential to develop further the motivational interviewing approach } \\
\text { within the oral health field. }\end{array}$ & N/A & 13 \\
\hline \multirow[t]{7}{*}{ Oral cancer } & $\begin{array}{l}\text { What are the reasons for delay in } \\
\text { seeking help from a clinician among } \\
\text { young oral cancer patients? }\end{array}$ & $\begin{array}{l}\text { The study confirms gaps in understanding and awareness of oral } \\
\text { cancer. Most survey participants had heard of oral cancer. However, } \\
\text { they did not think their symptoms were indicative of cancer and they } \\
\text { self-managed the problem. The culture of not bothering the GP/ } \\
\text { GDP unless the condition was perceived as serious is a barrier to early } \\
\text { diagnosis and treatment. }\end{array}$ & $\mathrm{N} / \mathrm{A}$ & 106 \\
\hline & $\begin{array}{l}\text { Are current screening methods } \\
\text { effective in reducing cancer } \\
\text { mortality? }\end{array}$ & $\begin{array}{l}\text { Although there is evidence that a visual examination as part of a } \\
\text { population-based screening programme reduced the mortality rate of } \\
\text { oral cancer in high-risk individuals, whilst producing a stage shift and } \\
\text { improvement in survival rates across the population as a whole, the } \\
\text { evidence is limited to one study and is associated with a high risk of bias. }\end{array}$ & $1 \mathrm{a}$ & 103 \\
\hline & $\begin{array}{l}\text { Does the use of toluidine blue as an } \\
\text { adjunctive tool for visual screening } \\
\text { of the mouth result in the increased } \\
\text { detection of oral premalignant lesions? }\end{array}$ & $\begin{array}{l}\text { This trial does not provide any new evidence to support or refute } \\
\text { the use of toluidine blue as an adjunctive tool for detection of oral } \\
\text { premalignant lesions. }\end{array}$ & $2 b$ & 104 \\
\hline & $\begin{array}{l}\text { What is the risk of and interval to } \\
\text { progression to oral cancer in patients } \\
\text { diagnosed with oral dysplasia? }\end{array}$ & $\begin{array}{l}\text { Oral dysplasia showed a significant rate of transformation to cancer, } \\
\text { which was related to grade, and was decreased significantly but not } \\
\text { eliminated by excision. Findings suggest the need for surgical excision } \\
\text { and continued surveillance, particularly in high-grade lesions. }\end{array}$ & $2 b$ & $91-92$ \\
\hline & $\begin{array}{l}\text { What is the effect of total exposure } \\
\text { and exposure rate for alcohol and } \\
\text { smoking on the risk of head and } \\
\text { neck cancer? }\end{array}$ & $\begin{array}{l}\text { The main findings reported were that fewer cigarettes smoked per } \\
\text { day for many years gave a greater risk for head and neck cancer } \\
\text { than many cigarettes smoked per day for fewer years. For alcohol } \\
\text { consumption, it was the other way round; heavy drinking per day } \\
\text { for a few years gave a greater risk for head and neck cancer than } \\
\text { fewer drinks per day for many years. }\end{array}$ & $3 a$ & $89-90$ \\
\hline & $\begin{array}{l}\text { Is diagnostic delay in oral cancer } \\
\text { related to advanced stage disease at } \\
\text { diagnosis? }\end{array}$ & $\begin{array}{l}\text { The probability for people with delayed diagnosis to present with an } \\
\text { advanced-stage tumour at diagnosis was significantly higher than } \\
\text { that of individuals with no delay in diagnosis. }\end{array}$ & $\mathrm{N} / \mathrm{A}$ & 24 \\
\hline & $\begin{array}{l}\text { What are the socioeconomic risk } \\
\text { factors for head and neck cancers? }\end{array}$ & $\begin{array}{l}\text { A high risk of head and neck cancer was consistently associated } \\
\text { with poor socioeconomic circumstances. There were strong links for } \\
\text { specific components but smoking dominated the overall profile of } \\
\text { risk. More detailed research into the nature of such associations is } \\
\text { needed in the future. }\end{array}$ & $\mathrm{N} / \mathrm{A}$ & $57-58$ \\
\hline $\begin{array}{l}\text { Oral } \\
\text { medicine }\end{array}$ & $\begin{array}{l}\text { What drugs can be used to treat oral } \\
\text { submucous fibrosis? }\end{array}$ & $\begin{array}{l}\text { There are few high-quality studies available and the present drug } \\
\text { treatments are in general empirical and treat only symptoms. } \\
\text { There is a need for high-quality RCTs in this area, especially studies } \\
\text { involving combined and sequential therapy. }\end{array}$ & $1 b$ & 56 \\
\hline Oral surgery & $\begin{array}{l}\text { What is the effectiveness of primary } \\
\text { insertion of dental implants in people } \\
\text { who have head and neck cancer? }\end{array}$ & $\begin{array}{l}\text { It remains unknown whether the outcomes of extra-oral and } \\
\text { intraoral implants are comparable, as a function of primary or } \\
\text { secondary placement, with or without subsequent radiotherapy. } \\
\text { With regard to both intra- and extra-oral implants, international } \\
\text { cooperative efforts are needed to determine which patients may } \\
\text { benefit from primary implant placement and where a delayed } \\
\text { strategy seems the most advantageous. }\end{array}$ & $\mathrm{N} / \mathrm{A}$ & $52-53$ \\
\hline
\end{tabular}




\begin{tabular}{|c|c|c|c|c|}
\hline \multirow[t]{5}{*}{ Orthodontics } & $\begin{array}{l}\text { What is the effect of orthodontic } \\
\text { treatment on root resorption? }\end{array}$ & $\begin{array}{l}\text { The key point to take from this review is that, whilst orthodontic } \\
\text { treatment is associated with an increased incidence and severity of } \\
\text { external apical root resorption, it is not currently possible to determine } \\
\text { which patients are at particular risk. Until better evidence becomes } \\
\text { available, all prospective orthodontic patients should be warned of the } \\
\text { possibility of root resorption as part of the consent process }\end{array}$ & $1 a$ & 88 \\
\hline & $\begin{array}{l}\text { In patients requiring supplementing } \\
\text { anchorage during orthodontic } \\
\text { treatment are midpalatal implants as } \\
\text { effective as headgear? }\end{array}$ & $\begin{array}{l}\text { The use of palatal implants to reinforce anchorage was as effective as } \\
\text { extraoral anchorage with headgear. }\end{array}$ & $1 b$ & 115 \\
\hline & $\begin{array}{l}\text { Does interceptive rapid maxillary } \\
\text { expansion improve the eruption rates } \\
\text { of palatally displace canines? }\end{array}$ & $\begin{array}{l}\text { The effectiveness of this technique is similar to success rates cited } \\
\text { with extraction of deciduous canines alone or, combined with } \\
\text { orthodontic treatment with fixed appliances. }\end{array}$ & $1 b$ & $86-87$ \\
\hline & $\begin{array}{l}\text { What proportion of people } \\
\text { undergoing orthognathic treatment } \\
\text { to correct dentofacial deformities } \\
\text { also have temporomandibular joint } \\
\text { disorders (TMD)? }\end{array}$ & $\begin{array}{l}\text { The diversity of diagnostic criteria and classification methods used } \\
\text { in the included studies makes interstudy comparisons difficult. } \\
\text { Well-designed studies are needed that have standardised diagnostic } \\
\text { criteria and classification methods for TMD. }\end{array}$ & $\mathrm{N} / \mathrm{A}$ & $82-85$ \\
\hline & $\begin{array}{l}\text { What proportion of orthognathic } \\
\text { patients who do not have signs or } \\
\text { symptoms of TMD preoperatively } \\
\text { then develop TMD signs or } \\
\text { symptoms postsurgery? }\end{array}$ & $\begin{array}{l}\text { Although orthognathic surgery should not be advocated solely for } \\
\text { treating TMD, patients having orthognathic treatment for correction } \\
\text { of their dentofacial deformities and who are also suffering from TMD } \\
\text { appear more likely to see improvement in their signs and symptoms } \\
\text { than deterioration. }\end{array}$ & $\mathrm{N} / \mathrm{A}$ & $82-85$ \\
\hline \multirow[t]{4}{*}{$\begin{array}{l}\text { Paediatric } \\
\text { Dentistry }\end{array}$} & $\begin{array}{l}\text { Is there a relationship between } \\
\text { socioeconomic status and traumatic } \\
\text { dental injuries? }\end{array}$ & $\begin{array}{l}\text { The absence of a consistently demonstrable correlation between } \\
\text { socioeconomic status and dental trauma may lie as much with the } \\
\text { heterogeneity of study methodology as the presence of a true lack of } \\
\text { association. }\end{array}$ & $1 b$ & 78 \\
\hline & $\begin{array}{l}\text { What is the best treatment option } \\
\text { for permanent teeth with avulsion } \\
\text { injuries? }\end{array}$ & $\begin{array}{l}\text { The available evidence suggests that extra-oral endodontic } \\
\text { treatment is not detrimental for teeth replanted after more than } \\
60 \text { min dry time. Studies with moderate/ high risk of bias indicate } \\
\text { that soaking in thymosin alpha } 1 \text { and gentamycin sulphate followed } \\
\text { by hyperbaric oxygen may be advantageous but these strategies } \\
\text { have not previously been reported as interventions for avulsed teeth } \\
\text { and await further validation. More evidence with low risk of bias is } \\
\text { required and, with the low incidence of avulsed teeth, collaborative } \\
\text { multicentre trials are indicated. }\end{array}$ & $2 a$ & $42-43$ \\
\hline & $\begin{array}{l}\text { What is the link between parental } \\
\text { and child dental fear? }\end{array}$ & $\begin{array}{l}\text { The narrative synthesis as well as the meta-analysis demonstrate } \\
\text { a significant relationship between parental and child dental fear, } \\
\text { particularly in children aged } 8 \text { years and under. }\end{array}$ & $2 b$ & 77 \\
\hline & $\begin{array}{l}\text { In people who have ankylosed } \\
\text { permanent anterior teeth, what } \\
\text { treatment options are effective? }\end{array}$ & $\begin{array}{l}\text { There is no evidence from RCTs about the comparative effectiveness } \\
\text { of the different treatment options for ankylosed permanent front } \\
\text { teeth. The lack of high-level evidence for the management of this } \\
\text { health problem emphasises the need for well-designed clinical trials. }\end{array}$ & $\mathrm{N} / \mathrm{A}$ & 44 \\
\hline \multirow[t]{5}{*}{$\begin{array}{l}\text { Periodontal } \\
\text { disease }\end{array}$} & $\begin{array}{l}\text { Is there a relationship between } \\
\text { periodontal therapy and glycaemic } \\
\text { control in people with diabetes? }\end{array}$ & $\begin{array}{l}\text { There is some evidence of improvement in metabolic control in } \\
\text { people with diabetes, after treating periodontal disease. There } \\
\text { are few studies available and individually these lacked the power } \\
\text { to detect a significant effect. Most of the participants in the } \\
\text { study had poorly controlled type } 2 \text { DM and there were little data } \\
\text { from randomised trials on the effects on people with type } 1 \text { DM. } \\
\text { Improving periodontal health is an important objective in itself. } \\
\text { However, in order to understand the potential of this treatment to } \\
\text { improve glycaemic control among people with diabetes, larger, } \\
\text { carefully conducted and reported studies are needed. }\end{array}$ & $1 a$ & $73-74$ \\
\hline & $\begin{array}{l}\text { Does the treatment of periodontal } \\
\text { disease in mid-pregnancy prevent } \\
\text { preterm birth, foetal growth } \\
\text { restriction, and preeclampsia? }\end{array}$ & $\begin{array}{l}\text { The evidence provided by the present study does not support the } \\
\text { hypothesis that treatment of periodontal disease during pregnancy } \\
\text { in this population prevents preterm birth, foetal growth restriction, } \\
\text { or pre-eclampsia. Periodontal treatment was not hazardous to the } \\
\text { women or their pregnancies. }\end{array}$ & $1 b$ & 18 \\
\hline & $\begin{array}{l}\text { Is there an association between } \\
\text { ischemic heart disease and } \\
\text { periodontitis in middle-aged and } \\
\text { elderly women? }\end{array}$ & $\begin{array}{l}\text { In the present study, periodontitis did not seem to have a statistically } \\
\text { significant relationship with IHD. The number of missing teeth } \\
\text { showed a strong association with IHD, and this may act as a proxy } \\
\text { variable tapping an array of different risk factors and behaviours. }\end{array}$ & $1 b$ & $20-21$ \\
\hline & $\begin{array}{l}\text { In people undergoing periodontal } \\
\text { treatment of multirooted teeth } \\
\text { with furcation involvement, what } \\
\text { is the survival rate and incidence of } \\
\text { complication at } 5 \text { years? }\end{array}$ & $\begin{array}{l}\text { The data suggest high levels of tooth retention comparable with } \\
\text { implant-supported restorations in the posterior mandible and } \\
\text { maxilla. The level of evidence is not high and there may be an } \\
\text { overestimation of true retention rates, but similar comments are } \\
\text { applicable to much of the relevant implant literature. }\end{array}$ & $2 b$ & $38-39$ \\
\hline & $\begin{array}{l}\text { What is the effect of local and } \\
\text { systemic risk factors on tooth loss } \\
\text { during long-term periodontal } \\
\text { maintenance? }\end{array}$ & $\begin{array}{l}\text { The considerable heterogeneity found among studies did not } \\
\text { allow definitive conclusions. However, age, smoking and initial } \\
\text { tooth prognosis were found to be associated with tooth loss during } \\
\text { periodontal maintenance. }\end{array}$ & $\mathrm{N} / \mathrm{A}$ & $75-76$ \\
\hline $\begin{array}{l}\text { Restorative } \\
\text { dentistry }\end{array}$ & $\begin{array}{l}\text { Is modern surgical endodontic } \\
\text { treatment effective and what factors } \\
\text { influence the outcome? }\end{array}$ & $\begin{array}{l}\text { Surgical endodontic treatment under magnification and illumination } \\
\text { with no or minimal bevel root-end resection, ultrasonic retrograde } \\
\text { canal preparation to a depth of } 3-4 \mathrm{~mm} \text {, and retrograde root canal } \\
\text { filling is a highly successful treatment. }\end{array}$ & $1 \mathrm{a}$ & $71-72$ \\
\hline
\end{tabular}




\begin{tabular}{|c|c|c|c|c|}
\hline & $\begin{array}{l}\text { Does ozone application reduce } \\
\text { dentine hypersensitivity? }\end{array}$ & $\begin{array}{l}\text { The results showed a reduction in dentine hypersensitivity in both } \\
\text { test and control groups, but the difference between the two groups } \\
\text { was not statistically significant. }\end{array}$ & $1 \mathrm{~b}$ & 70 \\
\hline & $\begin{array}{l}\text { Do ceramic CAD/CAM crowns } \\
\text { have similar long-term outcomes to } \\
\text { conventional gold crowns? }\end{array}$ & $\begin{array}{l}\text { This trial, at moderate risk for bias, found no statistically significant } \\
\text { differences between gold and Everest HPC crowns for a } 12 \text {-month } \\
\text { observation period. A longer observation period, with a sample size } \\
\text { calculation and low attrition rates is needed to establish clinically } \\
\text { relevant findings. }\end{array}$ & $1 b$ & $25-26$ \\
\hline & $\begin{array}{l}\text { What are the } 5 \text {-year survival rates } \\
\text { and incidences of complications } \\
\text { associated with ceramic abutments } \\
\text { compared with metal abutments? }\end{array}$ & $\begin{array}{l}\text { All ceramic abutments for implants seem to be a good option for } \\
\text { long term implant restoration in the aesthetic zone but due to } \\
\text { the limited number of clinical studies found, the results should be } \\
\text { interpreted with caution. }\end{array}$ & $1 b$ & $68-69$ \\
\hline & $\begin{array}{l}\text { In symptomatic patients who have } \\
\text { previously had endodontic treatment, } \\
\text { is nonsurgical treatment more } \\
\text { effective than endodontic surgery? }\end{array}$ & $\begin{array}{l}\text { On the basis of these results it appears that endodontic surgery offers } \\
\text { more favourable initial success, but nonsurgical retreatment offers a } \\
\text { more favourable long-term outcome. }\end{array}$ & $2 \mathrm{~b}$ & $54-55$ \\
\hline & $\begin{array}{l}\text { What are the indicators for success in } \\
\text { prosthodontic treatment? }\end{array}$ & $\begin{array}{l}\text { There remains a paucity of research in this area. From the best available } \\
\text { data, construction of technically correct dentures, a well-formed } \\
\text { mandibular ridge and accuracy of jaw relations are positive indicators } \\
\text { for success. Patient neuroticism and a poorly formed mandibular ridge } \\
\text { are negative indicators for success. Other prognostic indicators have } \\
\text { not been shown to be of significant value. There exists a minority of } \\
\text { patients who will never adapt to any conventional complete denture. } \\
\text { This problem is more acute in the mandible than the maxilla. There is } \\
\text { need for further research in this area. }\end{array}$ & N/A & 47 \\
\hline & $\begin{array}{l}\text { In adult patients with defective } \\
\text { amalgam restorations is repair } \\
\text { with amalgam more effective than } \\
\text { replacement? }\end{array}$ & $\begin{array}{l}\text { There are no published randomised controlled clinical trials } \\
\text { relevant to this review question. There is therefore a need for } \\
\text { methodologically sound randomised controlled clinical trials that are } \\
\text { reported according to the CONSORT statement. }\end{array}$ & $\mathrm{N} / \mathrm{A}$ & 111 \\
\hline & $\begin{array}{l}\text { In adult patients with defective resin } \\
\text { composite restorations is repair with } \\
\text { resin composite more effective than } \\
\text { replacement? }\end{array}$ & $\begin{array}{l}\text { There are no published randomised controlled clinical trials } \\
\text { relevant to this review question. There is therefore a need for } \\
\text { methodologically sound randomised controlled clinical trials that are } \\
\text { reported according to the CONSORT statement. }\end{array}$ & N/A & 112 \\
\hline & $\begin{array}{l}\text { What is the frequency of tooth pain } \\
\text { at } 6 \text { months in patients undergoing } \\
\text { root canal therapy? }\end{array}$ & $\begin{array}{l}\text { The frequency of all-cause persistent tooth pain after endodontic } \\
\text { procedures was estimated to be } 5.3 \% \text {, with higher quality studies } \\
\text { suggesting }>7 \% \text {. }\end{array}$ & N/A & 114 \\
\hline & $\begin{array}{l}\text { How do the survival and } \\
\text { complication rates of implant- } \\
\text { supported fixed partial dentures with } \\
\text { cantilevers compare with implanted- } \\
\text { supported single tooth and } \\
\text { implanted-supported fixed partial } \\
\text { dentures without cantilevers? }\end{array}$ & $\begin{array}{l}\text { This review does add to our current knowledge base the observation } \\
\text { that the implant-supported cantilever fixed bridge appears to give } \\
\text { high success rates. Further data are needed to confirm or deny } \\
\text { whether their survival and complication rates are as impressive as the } \\
\text { non-cantilever implant-supported prosthesis, including the implant- } \\
\text { supported single tooth crown. }\end{array}$ & N/A & $48-9$ \\
\hline & $\begin{array}{l}\text { What are the survival rates of short- } \\
\text { span implant-supported cantilever } \\
\text { fixed dental prostheses and the } \\
\text { incidence of technical and biological } \\
\text { complications over } 5 \text { years? }\end{array}$ & $\begin{array}{l}\text { There is growing evidence that implant-supported cantilever fixed } \\
\text { dental prostheses are a viable treatment option, research that is } \\
\text { larger in scope will be required before definitive recommendations } \\
\text { can be made. }\end{array}$ & N/A & $50-51$ \\
\hline $\begin{array}{l}\text { Service } \\
\text { organisation } \\
\text { and delivery } \\
\text { of care }\end{array}$ & $\begin{array}{l}\text { In dental practice are multifaceted } \\
\text { guideline-implementation strategies } \\
\text { more effective than dissemination } \\
\text { alone? }\end{array}$ & $\begin{array}{l}\text { Multifaceted intervention had a moderate but relevant effect on the } \\
\text { performance of general dental practitioners, which is consistent with } \\
\text { other findings in primary care. }\end{array}$ & $1 \mathrm{~b}$ & 40 \\
\hline & $\begin{array}{l}\text { Is there a difference between the } \\
\text { oral health of adults with intellectual } \\
\text { disabilities and the general } \\
\text { population? }\end{array}$ & $\begin{array}{l}\text { Preventive programmes for these groups and their carers are } \\
\text { important, as they are for other sectors of the population. They need } \\
\text { to be delivered by people who understand the needs of people with } \\
\text { learning disabilities. }\end{array}$ & $\mathrm{N} / \mathrm{A}$ & 81 \\
\hline \multicolumn{5}{|c|}{$\begin{array}{l}\text { RCT - Randomised controlled trial } \\
\text { GDP- general dental practitioner } \\
\text { IHD - ischemic heart disease } \\
\text { DM - diabetes mellitus } \\
\text { GP - general medical practitioner } \\
\text { CAD/CAM - computer-aided design/computer-aided manufacturing } \\
\text { CONSORT - Consolidated Standards of Reporting Trials statement (www.consort-statement.org/) }\end{array}$} \\
\hline
\end{tabular}

1. Lawrence A, Richards D. Questions answered in EBD volumes 1 and 2. Evid Based Dent 2002; 3: 27-29.

2. Richards D. Questions and answers in EBD volumes 3 and 4. Evid Based Dent 2003; 4: 94-97.

3. Richards D. Questions and answers and guidelines in EBD volume 5. Evid Based Dent 2004; 5: 110-112.

4. Richards D. Questions and answers and guidelines in EBD volume 6. Evid Based Dent 2005; 6: 104-107.

5. Richards D. Questions and answers and guidelines in EBD volume 7. Evid Based Dent 2006; 7: 109-113.

6. Richards D. Questions and answers and guidelines in EBD volume 8. Evid Based Dent 2007; 8: 118-121.

7. Richards D. Questions and answers and guidelines in EBD volume 9. Evid Based Dent 2008; 9: 121-125.

8. Richards D. Questions and answers and guidelines in EBD volume 10. Evid Based Dent 2009; 9: 120-123.

9. Richards D. Not all evidence is created equal — so what is good evidence? Evid Based Dent 2003; 4: 17-18. 